\title{
Identification of dairy farm management practices associated with the presence of psychrotolerant sporeformers in bulk tank milk ${ }^{1}$
}

\author{
S. N. Masiello, ${ }^{*}$ N. H. Martin, ${ }^{*}$ R. D. Watters, † D. M. Galton, † Y. H. Schukken, $\ddagger$ M. Wiedmann, ${ }^{*}$ and K. J. Boor*² \\ *Milk Quality Improvement Program, Department of Food Science, \\ †Department of Animal Science, and \\ †Quality Milk Production Services, College of Veterinary Medicine, Cornell University, Ithaca, NY 14853
}

\section{ABSTRACT}

Some strains of sporeforming bacteria (e.g., Bacillus spp. and Paenibacillus spp.) can survive pasteurization and subsequently grow at refrigeration temperatures, causing pasteurized fluid milk spoilage. To identify farm management practices associated with different levels of sporeformers in raw milk, a bulk tank sample was obtained from and a management and herd health questionnaire was administered to 99 New York State dairy farms. Milk samples were spore pasteurized $\left[80^{\circ} \mathrm{C}\right.$ $\left(176^{\circ} \mathrm{F}\right)$ for $\left.12 \mathrm{~min}\right]$ and subsequently analyzed for most-probable number and for sporeformer counts on the initial day of spore pasteurization (SP), and after refrigerated storage $\left(6^{\circ} \mathrm{C}\right)$ at 7,14 , and $21 \mathrm{~d}$ after SP. Management practices were analyzed for association with sporeformer counts and bulk tank somatic cell counts. Sixty-two farms had high sporeformer growth ( $\geq 3 \log \mathrm{cfu} / \mathrm{mL}$ at any day after $\mathrm{SP}$ ), with an average sporeformer count of $5.20 \pm 1.41$ mean $\log _{10} \mathrm{cfu} / \mathrm{mL}$ at $21 \mathrm{~d}$ after SP. Thirty-seven farms had low sporeformer numbers $(<3 \log \mathrm{cfu} / \mathrm{mL}$ for all days after SP), with an average sporeformer count of $0.75 \pm 0.94$ mean $\log _{10}$ $\mathrm{cfu} / \mathrm{mL}$ at $21 \mathrm{~d}$ after SP. Farms with $>25 \%$ of cows with dirty udders in the milking parlor were 3.15 times more likely to be in the high category than farms with $\leq 10 \%$ of milking cows with dirty udders. Farms with $<200$ cows were 3.61 times more likely to be in the high category than farms with $\geq 200$ cows. Management practices significantly associated with increased bulk tank somatic cell count were a lack of use of the California mastitis test at freshening and $>25 \%$ of cows with dirty udders observed in the milking parlor. Changes in management practices associated with cow cleanliness

Received January 13, 2014.

Accepted March 18, 2014.

${ }^{1}$ Any opinions, findings, conclusions, or recommendations expressed in the publication are those of the authors and do not necessarily reflect the view of the National Institute of Food and Agriculture (NIFA, Washington, DC) or the USDA (Washington, DC).

${ }^{2}$ Corresponding author: kjb4@cornell.edu may directly ensure longer shelf life and higher quality of pasteurized fluid milk.

Key words: Bacillus spp., Paenibacillus spp., spoilage, management practice

\section{INTRODUCTION}

Food loss due to microbial spoilage is costly for the United States (Buzby and Hyman, 2012). Of the $>5$ billion gallons of pasteurized fluid milk meant for consumption in the United States every year, one-fifth is discarded by consumers and foodservice businesses (IDFA, 2010; Gunders, 2012). Bacterial spoilage is the predominant limiting factor in the shelf life of pasteurized fluid milk (Boor, 2001; Durak et al., 2006). Microbes can be present in pasteurized milk through 2 different routes: (1) survival of pasteurization by bacteria present in raw milk and (2) postpasteurization contamination of the product. Microbes associated with the former route of spoilage are generally grampositive sporeformers (Boor and Murphy, 2002; Huck et al., 2007a).

In general, in the absence of postpasteurization contamination, sporeforming bacteria are the predominant residual organisms in pasteurized fluid milk. Gram-positive Bacillus spp. and Paenibacillus spp. form heat-resistant spores that can withstand HTST pasteurization commonly used for fluid milk processing (Collins, 1981; Fromm and Boor, 2004; Ranieri et al., 2009). The ability of these organisms to survive heat treatment and of certain strains to grow at refrigerated storage temperatures results in milk spoilage (Washam et al., 1977; Huck et al., 2008). Whereas Bacillus is usually the predominant genus present up to $7 \mathrm{~d}$ postpasteurization in milk held at $6^{\circ} \mathrm{C}$, Paenibacillus spp. often dominate later in shelf life (i.e., at $17 \mathrm{~d}$ and beyond; Fromm and Boor, 2004; Ranieri et al., 2009). The metabolic activities of these sporeforming spoilage bacteria can lead to loss of product quality, including curdling and off-odors or -flavors (Ageitos et al., 2007; Dutt et al., 2009). Reduction or elimination of these bacterial contaminants can result in extension of fluid 
milk shelf life, which would advance the dairy industry by providing overall higher product quality.

Eliminating sporeforming bacteria is challenging, as these organisms are ubiquitously found in the environment, including in soil, on plant surfaces, in decaying matter, and in mammalian digestive tracts (Gilliam et al., 1984; Gilliam, 1985; Sarkar, 1991; Fredrickson and Onstott, 1996; Nicholson, 2002). Sporeforming bacteria have been isolated from the dairy farm environment. For example, Bacillus sporothermodurans was isolated from feed concentrates on 17 Belgian dairy farms (Scheldeman et al., 2002). Bacillus spp. also were prevalent on Scottish dairy farms, with Bacillus licheniformis most commonly isolated from the dairy farm environment (excluding grass and soil samples) and Bacillus cereus, Bacillus circulans, Bacillus firmus, B. licheniformis, Bacillus subtilis, Bacillus coagulans, Bacillus sphaericus, and Bacillus mycoides isolated from raw bulk tank/ silo milk (Crielly et al., 1994). Paenibacillus spp. have been isolated from silage, dairy cow feed concentrate, and raw milk (Vaerewijck et al., 2001; te Giffel et al., 2002; Scheldeman et al., 2004). Sporeformers have been isolated along the dairy product processing continuum, from milk trucks to packaged final products, with plant factors such as processing parameters, including pasteurization temperatures (Ranieri et al., 2009; Martin et al., 2011), significantly affecting microbiological quality of the final pasteurized product. Identification of the same bacterial subtypes in both raw and pasteurized milk samples suggests that pasteurized fluid milk spoilage can result from bacteria that enter raw milk on the farm (Huck et al., 2007b).

We hypothesized that identifying specific farm practices that associate with different sporeformer levels could allow development of specific, actionable recommendations for production of raw bulk tank milk with low sporeformer numbers. Therefore, the objectives of this study were to (1) assess the prevalence and diversity of psychrotolerant sporeformers isolated from bulk tank milk and (2) evaluate possible associations between on-farm management practices and levels of psychrotolerant sporeformers in bulk tank milk.

\section{MATERIALS AND METHODS}

\section{Herd Selection}

A cross-sectional observational study was conducted on 99 New York State (NYS) dairy farms from May 2009 to June 2010. Herds were selected from the Quality Milk Production Services (QMPS; College of Veterinary Medicine, Cornell University, Ithaca, NY) program clientele at 4 different QMPS locations, representing different regions in NYS, including Ithaca (14 herds),
Canton (29 herds), Cobleskill (47 herds), and Geneseo (9 herds). Farms were selected based on willingness to participate; participating farms represented a range of herd sizes and historical bulk tank SCC (BtSCC) as detailed in the Results section. All participants were fully informed of the design of the study, the nature of the data being collected and its future use, and were aware that the study was voluntary. Each participant signed an informed consent document acknowledging the above items.

\section{Survey Design}

The survey used in this study was adapted from an existing QMPS survey that included questions on herd health, housing cleanliness, equipment maintenance, milking time procedures, and medication usage. The revised survey was a 1-page document that included all of these topics except medication usage. Percentage dirty udders in the milking area was evaluated using the University of Wisconsin Udder Hygiene Scoring Chart (Dairy Team Extension, 2002). The factor was defined as the percentage of cows whose rear legs and rear udder area were moderately covered with dirt (10-30\% of surface area) or covered with caked on dirt $(>30 \%$ of surface area). The questions on the survey were either open ended or close ended with binary (yes/no) answers. The survey was designed to be administered orally to the participant. This survey was pretested for ease of understanding on QMPS staff who would be administering the survey as well as on the first 5 farms included in the study.

\section{Survey Administration and Bulk Tank Sampling}

Quality Milk Production Services technicians were trained on survey administration by a supervisor. Each location had a single, designated, and trained technician who administered the survey and collected samples. Technicians administering the surveys were trained to obtain objective answers without being leading, to focus on quantitative/numeric answers, and to follow training guides for any necessary subjective scores or observations. Surveys were administered during the same farm visit as when bulk tank samples were obtained.

Bulk tank milk at each farm was sampled using 2 sterile dip vials and 1 National Dairy Herd Information Association (Verona, WI) vial, which were immediately stored on ice packs in a cooler and held at $\leq 6^{\circ} \mathrm{C}$. Raw bulk tank milk samples ( $250 \mathrm{~mL}$ in each of 2 vials) were shipped overnight to the laboratory in Styrofoam coolers packed with ice packs. Temperature data recorders were included in each shipment and the temperature 
of the sample was recorded immediately upon arrival to the Milk Quality Improvement Program laboratory (Department of Food Science, Cornell University). Any samples with temperatures $>6^{\circ} \mathrm{C}$ upon arrival were rejected and the farm was resampled. The Dairy Herd Information Association vials were shipped directly from QMPS locations to Dairy One (Ithaca, NY) for BtSCC analysis using a Fossomatic FC ESCC automated SCC reader (Foss Inc., Hillerød, Denmark).

\section{Microbiological Evaluation of Milk Samples}

For each farm, the 2 sample vials ( $250 \mathrm{~mL}$ each) were commingled into 1 sterile $500-\mathrm{mL}$ glass bottle. Raw milk samples were inverted completely 25 times before removal of an aliquot for microbiological analyses, which included (1) total bacteria count on SPC agar (Difco; BD Diagnostics, Franklin Lakes, NJ), as described by Laird et al. (2004); (2) psychrotrophic bacteria count (PBC; Laird et al., 2004); and (3) preliminary incubation (PI) count (Martin et al., 2011).

The remaining raw milk was distributed equally among 3 sterile $250-\mathrm{mL}$ glass bottles for spore pasteurization (SP), performed by heat treating each of the 3 bottles $(\sim 150 \mathrm{~mL}$ each $)$ at $80^{\circ} \mathrm{C}\left(176^{\circ} \mathrm{F}\right)$ for $12 \mathrm{~min}$ and then immediately cooling on ice. After cooling to $6^{\circ} \mathrm{C}$, the samples in each bottle were commingled into a sterile $500-\mathrm{mL}$ glass bottle. The bottle was fully inverted 25 times and $200-\mu \mathrm{L}$ samples were spiral plated onto duplicate SPC agar plates. The remaining sporepasteurized milk samples were then split equally into 3 sterile $250-\mathrm{mL}$ glass bottles and held at $6^{\circ} \mathrm{C}$ for microbiological testing (SPC) at 7, 14, and $21 \mathrm{~d}$ after SP. Additionally, a modified 5 tube most-probable-number (MPN) method (Davidson et al., 2004) was used to enumerate very low numbers of psychrotolerant sporeformers not achievable by plating techniques (Supplemental Figure S1, available online at http://dx.doi. org/10.3168/jds.2014-7938). The MPN method was performed on spore-pasteurized samples as follows: 10 $\mathrm{mL}$ of spore-pasteurized milk was aliquoted into each of 5 sterile screw-capped tubes, $1 \mathrm{~mL}$ of spore-pasteurized milk was aliquoted into each of 5 sterile screw-capped tubes containing $9 \mathrm{~mL}$ of sterile skim milk broth (1:10 dilution), and finally, $0.1 \mathrm{~mL}$ of spore-pasteurized milk was aliquoted into each of 5 sterile screw-capped tubes containing $9.9 \mathrm{~mL}$ of sterile skim milk broth (1:100 dilution). Each of the 15 tubes was vortexed and then incubated at $6^{\circ} \mathrm{C}$ for $21 \mathrm{~d}$ before spiral plating on SPC agar. Plates were evaluated for presence or absence of growth. The MPN data were interpreted into quantitative results using a 5-tube MPN table (Davidson et al., 2004).

\section{Bacterial Isolate Collection}

Bacterial colonies representing visually distinct morphologies (typically 1 to 4 colonies per sample) were selected and streaked for purity on brain-heart infusion (BHI) agar (Difco Laboratories Inc., Franklin Lakes, NJ) from SPC agar plates used for bacterial enumeration on each sampling date. Pure cultures were grown overnight in $\mathrm{BHI}$ broth at $32^{\circ} \mathrm{C}$ before freezing in $15 \%$ glycerol at $-80^{\circ} \mathrm{C}$. A total of 1,182 isolates were collected over the duration of the study. Isolate information can be found at the Food Microbe Tracker website (http://www.foodmicrobetracker.com).

\section{Molecular Characterization and Identification of Isolates}

Isolates selected for molecular characterization were obtained from spore-pasteurized milk samples plated on the initial day (DI) and d 7, 14, and 21. Isolates collected from MPN plates were not characterized. The methods described by Huck et al. (2007a) were used to determine species identification for psychrotolerant sporeformer isolates. Briefly, cultures were streaked for colony isolation from frozen stock onto BHI agar and grown at $32^{\circ} \mathrm{C}$ for $24 \mathrm{~h}$. A sterile toothpick was used to sample an isolated colony and PCR was performed to amplify the 632-bp rpoB gene fragment (Huck et al., 2007a). After verifying amplification by gel electrophoresis, DNA fragments were purified using the ExoSAP method (Dugan et al., 2002) and bidirectional sequencing with PCR primers was performed by the Life Sciences Core Laboratory Center (Cornell University) using Sanger sequencing. Genus and (or) species assignment were obtained using $16 \mathrm{~S}$ ribosomal DNA for isolates not identifiable with rpoB sequencing. Sequence alignment and allelic type (AT) assignment methods were as described by Ivy et al. (2012).

\section{Prediction of Cold-Growth Analysis of Isolates}

To identify isolates likely to be able to grow at refrigeration temperatures and, hence, to cause fluid milk spoilage, isolates obtained in this study were compared phylogenetically with sporeforming bacterial isolates that had been tested previously for cold-growth ability (defined as growth over $24 \mathrm{~d}$ at $6^{\circ} \mathrm{C}$; Ivy et al., 2012). Briefly, rроB AT from 444 isolates in this study were compared with all rpoB AT analyzed by Ivy et al. (2012) in a parsimony phylogenetic tree that was constructed using PAUP software (version 4; Sinauer Associates Inc., Sunderland, MA). Isolates were selected to reduce duplication, i.e., isolates from duplicate plates of the same milk sample with the same AT were eliminated to 
reduce overrepresentation of a given AT. Study isolates were considered to be members of previously described clades if they grouped closely with 1 or more of the earlier analyzed AT (Ivy et al., 2012).

\section{Statistical Analyses}

All statistical analyses were performed in SAS (version 9.3; SAS Institute Inc., Cary, NC). The distributions of sporeformer counts at each day of refrigerated storage were plotted. Individual farm sample results were separated into 2 categories based on the distributions of sporeformer numbers during the entire 21-d storage period at $6^{\circ} \mathrm{C}$; the low category indicated that sporeformer counts remained $<3 \log \mathrm{cfu} / \mathrm{mL}$ during the entire storage period and the high category indicated that sporeformer counts were $\geq 3 \log \mathrm{cfu} / \mathrm{mL}$ at any day during the storage period. Sporeformer count data and raw milk test data were logarithmically transformed before analyses. A correlation matrix analysis was performed between raw milk microbiological test results (raw milk SPC, PBC, and PI), MPN test results, and sporeformer counts at each day of refrigerated storage (DI and d 7, 14, and 21) to explore possible correlations using the restricted maximum likelihood method and calculation of coefficient of determination values.

Logistic regression analysis modeling for the high category data was used to assess associations between management practices and sporeformer categories. Both bivariate and multivariate models were investigated. Survey response categories were evaluated for possible correlations; if present, the more biologically relevant factor (determined by a closer relationship to the milking parlor area or milking practices) was chosen for analysis. Additionally, factor levels were assessed for potential collapse into fewer levels due to low distributions for different levels within a single factor. Variables having a significant $(P \leq 0.10)$ association in a bivariate logistic regression model with the high sporeformer category were included in a multivariate logistic regression model. Any nonsignificant $(P>0.10)$ variables were removed from the multivariate model using backward elimination (starting with the least significant factor). For BtSCC, SCC data were logarithmically transformed and analyzed using a simple linear regression model. Variables with significant $(P \leq$ $0.10)$ associations with the high sporeformer category in a bivariate linear regression model were subsequently included in a multivariate linear regression model. Variables with nonsignificant $(P>0.10)$ associations were removed from the multivariate model using backward elimination. A one-way ANOVA was used to identify differences between low and high categories $(P \leq 0.05)$ for each raw milk microbiological test and each day of refrigerated storage. A one-way ANOVA was also used to identify the distribution of MPN over the factor levels within the management practices "percentage dirty udders in the milking area" and "herd size" $(P \leq 0.05)$. Chi-squared tests were performed on the distribution of genera between the high and low categories and between days of refrigerated storage $(P \leq 0.05)$ and a Fisher exact test was performed on the distribution of clades classified as cold growing and non-cold growing between the high and low categories $(P \leq 0.05)$.

\section{RESULTS}

\section{Milk from Diverse Farms Showed 2 Distinct Microbial Growth Patterns Following SP and Subsequent Incubation at $6^{\circ} \mathrm{C}$}

Herd information collected included herd size, cow breed, number of milking cows, number of milkings per day, housing type, average milk production, and BtSCC. Herd sizes ranged from 15 to 3,100 cows, with a mean size of $265 \pm 484$ cows. Cows were housed in tie-stalls $(57 \%)$, freestalls $(15 \%)$, stanchions $(13 \%)$, or on pasture (15\%). Cow breeds included Holstein (51\%), Jersey (4\%), and multiple or mixed breeds (45\%). The number of lactating cows per farm ranged from 10 to 2,800 (mean of $279 \pm 472$ lactating cows), with farms milking between 1 and 3 times daily ( $5 \%$ at $1 \times, 75 \%$ at $2 \times$, and $20 \%$ at $3 \times$ ). Average milk production across farms was $8,308 \mathrm{~kg}(18,317 \mathrm{lbs}) \pm 3,282 \mathrm{~kg}(7,237 \mathrm{lbs})$ per cow per year and ranged from $1,564 \mathrm{~kg}(3,450 \mathrm{lbs})$ to $12,727 \mathrm{~kg}(28,060 \mathrm{lbs})$.

After milk collected from the 99 participating farms was treated by $\mathrm{SP}$ and then incubated at $6^{\circ} \mathrm{C}$, milk from 37 farms $(37 \%)$ showed limited or no bacterial growth $(<3 \log \mathrm{cfu} / \mathrm{mL}$ at each test day through $\mathrm{d}$ 21 after SP); these farms will be referred to as "lowcategory" farms. Milk from the other 62 farms (63\%) showed considerable bacterial growth after SP, reaching bacterial numbers of $\geq 3 \log \mathrm{cfu} / \mathrm{mL}$ during $21 \mathrm{~d}$ after SP (Figure 1); these farms will be referred to as "highcategory" farms. Milk from 48 of 62 farms (77\%) in the high category reached bacterial numbers of $\geq 20,000$ $\mathrm{cfu} / \mathrm{mL}$ on d 21 after SP and would not meet the standard of $<20,000 \mathrm{cfu} / \mathrm{mL}$ for grade A pasteurized milk set by the Pasteurized Milk Ordinance (FDA, 2011). At each day of refrigerated storage, bacterial numbers for the high- and low-category farms (Figure 1) differed significantly $(P \leq 0.001)$. The mean bacterial counts at d 21 after SP for samples from farms in the low and high categories were $0.75 \pm 0.94$ and $5.20 \pm 1.41 \log _{10} \mathrm{cfu} /$ $\mathrm{mL}$, respectively. Bacterial counts in the spore-treated samples will be referred to as "sporeformer counts" in all subsequent sections, as (1) the SP treatment should 


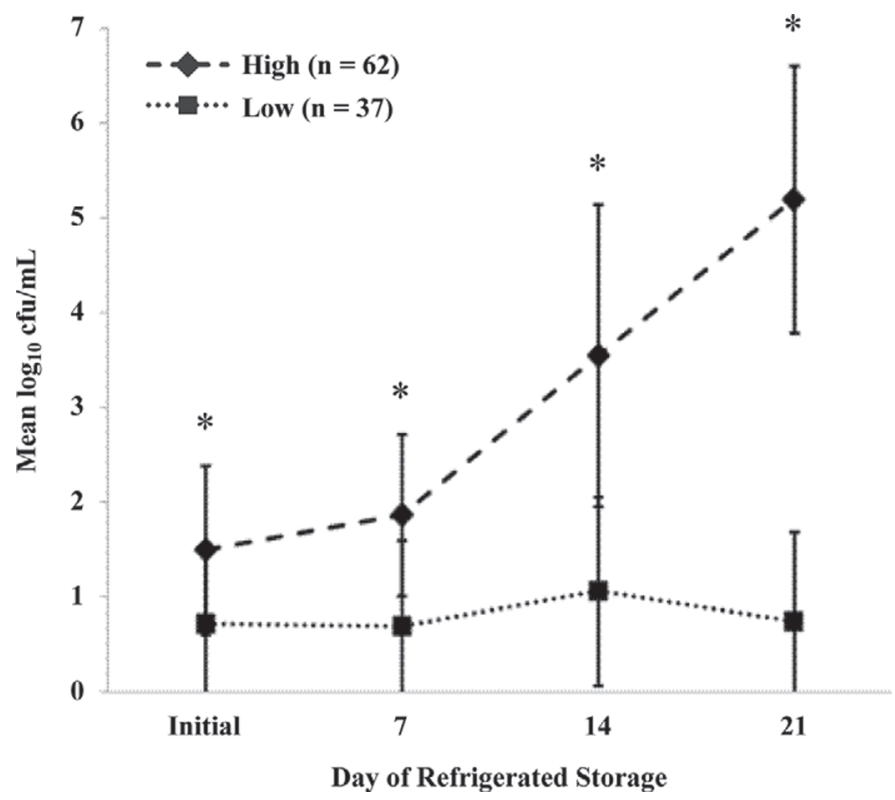

Figure 1. Sporeformer bacteria levels (mean $\log _{10} \mathrm{cfu} / \mathrm{mL}$ ) for spore-pasteurized $\left[80^{\circ} \mathrm{C}\left(176^{\circ} \mathrm{F}\right)\right.$ for $\left.12 \mathrm{~min}\right]$ milk from high- and lowcategory farms over $21 \mathrm{~d}$ after spore pasteurization at $6^{\circ} \mathrm{C}$ refrigerated storage. Error bars indicate mean $\pm \mathrm{SD}$ for each day of refrigerated storage. ${ }^{*} P \leq 0.001$

kill vegetative cells and (2) isolates obtained were classified into sporeformer genera (see below).

\section{Raw Milk Yielding SP-Treated Milk Samples that Were Classified into the Low and High Categories Differed in Selected Microbiological Raw Milk Parameters}

The BtSCC for the 99 milk samples evaluated ranged from 56,000 to 2,062,000 cells/mL; mean BtSCC for milk from the low- and high-category farms $(256,000$ and 368,000 cells $/ \mathrm{mL}$, respectively) were not significantly different (Table 1). Raw milk SPC ranged from 1.86 to $6.75 \log _{10} \mathrm{cfu} / \mathrm{mL}$; mean raw milk SPC values for milk from the low- and high-category farms (3.68 and 3.94 mean $\log _{10} \mathrm{cfu} / \mathrm{mL}$, respectively) also were not significantly different. Raw milk PI counts ranged from 2.30 to $7.11 \log _{10} \mathrm{cfu} / \mathrm{mL}$; mean raw milk PI counts for milk from the low- and high-category farms (4.75 and $5.39 \log _{10} \mathrm{cfu} / \mathrm{mL}$, respectively) were significantly different $(P=0.0045)$. The PBC for the raw milk samples ranged from 1.00 to $6.93 \log _{10} \mathrm{cfu} / \mathrm{mL}$; mean $\mathrm{PBC}$ for milk from the low- and high-category farms (2.41 and $3.11 \log _{10} \mathrm{cfu} / \mathrm{mL}$, respectively) were significantly different $(P=0.0027$; Table 1$)$. The MPN for psychrotolerant sporeformers (determined on SP-treated milk incubated at $6^{\circ} \mathrm{C}$ ) ranged from $<0.01$ to $>24 \mathrm{MPN} /$ $\mathrm{mL}$; mean MPN for milk from the low- and highcategory farms (0.11 and $2.13 \mathrm{MPN} / \mathrm{mL}$, respectively) were significantly different $(P=0.015$; Table 1$)$. The MPN data were available for 94 of 99 of the bulk tank samples. Overall, 10 of 35 samples categorized as low at d 21 after SP showed no growth in any of the MPN tubes (MPN <0.01), whereas only 3 of 59 samples in the high category showed MPN $<0.01$ (different at $P$ $=0.0014$; Fisher exact test). Further analysis showed significant $(P<0.05)$ correlation between each of the raw milk tests used (raw milk SPC, PI count, PBC, $\mathrm{MPN}$, and BtSCC) and d-21 sporeformer counts for all samples, including those from both low- and highcategory farms. These findings indicate that multiple microbiological tests provide insight into the overall microbiological quality of raw milk (i.e., poor-quality milk generally performs poorly in multiple tests). Coefficient of determination values were very low, however, ranging from 0.25 to 0.38 for raw milk SPC, PI count, PBC, $\mathrm{MPN}$, and BtSCC, indicating that raw milk tests do not show a good correlation with d-21 bacterial counts in SP-treated milk (i.e., results from the raw milk tests do not accurately predict d-21 bacterial counts).

\section{Bacillus and Paenibacillus Were the Predominant Sporeformer Genera Isolated from Milk Samples that Represented the Low and the High Categories}

A total of 444 representative bacterial isolates obtained from the 99 milk samples at different time points after SP treatment (Table 2) were characterized by $г$ rро $B$ sequencing, which enabled classification into genus, species, and AT. Not surprisingly, substantially more isolates were available from the samples in the high category (374 isolates) versus the low category (70 isolates). Virtually all isolates characterized represented either Bacillus spp. (71.4\%; 317/444 isolates) or Paenibacillus spp. (26.4\%; 117/444 isolates; Table 2). Lysinibacillus spp., Planococcaceae spp., Psychrobacillus spp., and Viridibacillus arvi/arenosi accounted for $2.2 \%(10 / 444)$ of the total isolates (Table 2). Genus distribution (Bacillus and Paenibacillus) did not differ significantly between isolates from samples in the low and high category $(P=0.87$; chi-squared test). Bacillus spp. represented $71.9 \%(269 / 374)$ and $68.6 \%$ $(48 / 70)$ of the isolates characterized from the high- and low-category farms, respectively; Paenibacillus spp. represented $26.7 \%(100 / 374)$ and $24.3 \%(17 / 70)$ of isolates, respectively. The predominant Bacillus and Paenibacillus spp. among the characterized isolates were B. licheniformis, Bacillus pumilus, and Bacillus weihenstephanensis (Table 2) and Paenibacillus odorifer and Paenibacillus cf. peoriae (Table 2), where cf. represents an unspecified identification, resembling the named species. Among all isolates obtained from milk at DI and d 7 after SP, 192 and 38 were classified as Bacillus 
Table 2. Numbers and prevalence of bacterial isolates obtained from spore-pasteurized $\left[80^{\circ} \mathrm{C}\left(176^{\circ} \mathrm{F}\right)\right.$ for 12 min] bulk tank milk samples from high- and low-category farms at the initial day (DI) and d 7, 14, and 21 of refrigerated storage at $6^{\circ} \mathrm{C}$

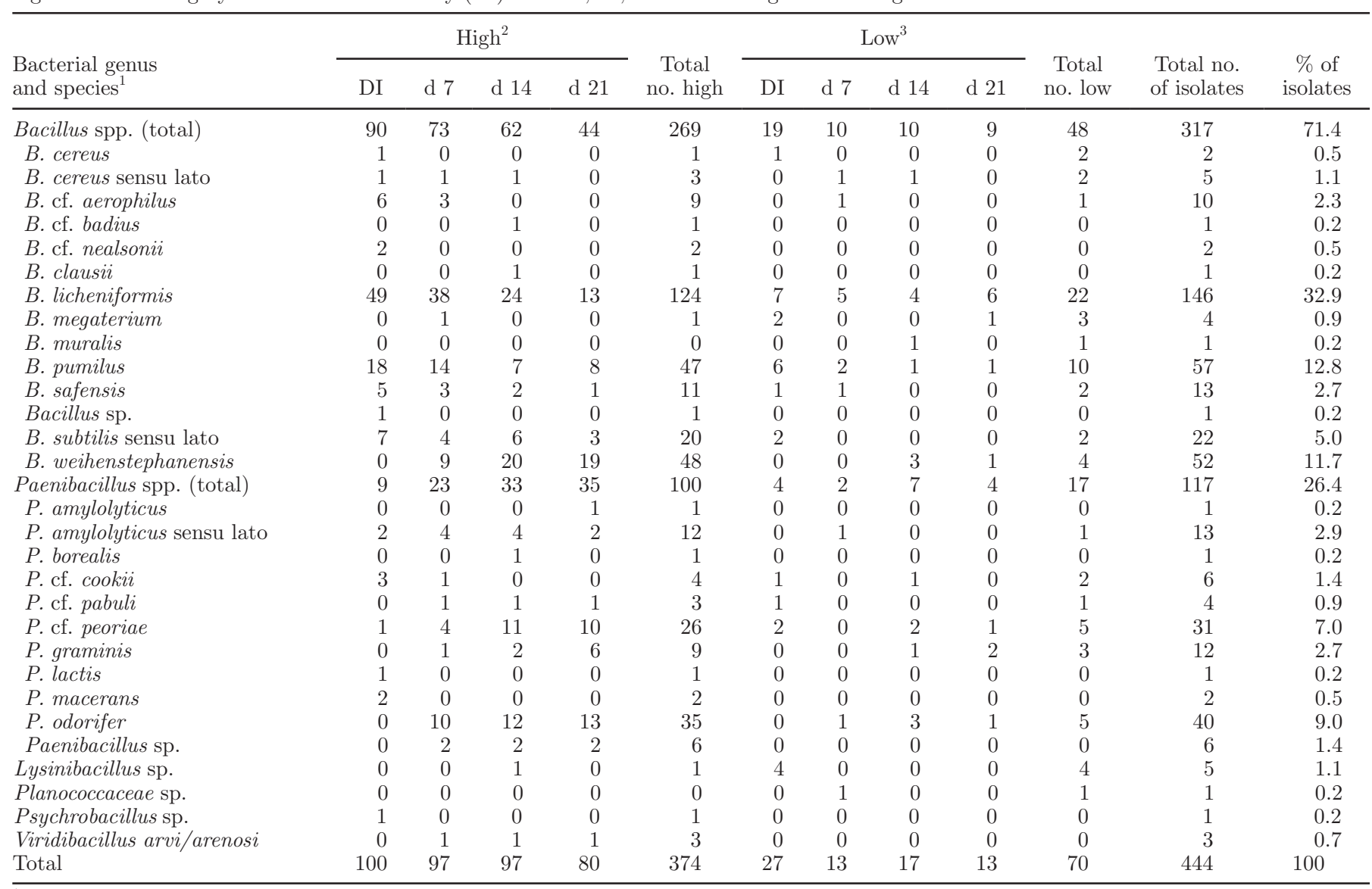

${ }^{1}$ Sensu lato $=$ in the broad sense; cf. $=$ unspecified identification, resembling the named species.

${ }^{2}$ Defined as bacterial count $\geq 3 \log \mathrm{cfu} / \mathrm{mL}$ at any day after spore pasteurization (SP).

${ }^{3}$ Defined as bacterial count $<3 \log \mathrm{cfu} / \mathrm{mL}$ for all days after SP.

Table 3. Classification into previously defined cold-growth clades of bacterial isolates obtained from sporepasteurized $\left[80^{\circ} \mathrm{C}\left(176^{\circ} \mathrm{F}\right)\right.$ for $\left.12 \mathrm{~min}\right]$ milk samples at $21 \mathrm{~d}$ of refrigerated storage $\left(6^{\circ} \mathrm{C}\right)$

\begin{tabular}{|c|c|c|c|}
\hline \multirow[b]{2}{*}{ Sporeformer clade $\mathrm{e}^{1,2}$} & \multirow{2}{*}{$\begin{array}{l}\text { Cold-growth } \\
\text { status }^{1,3}\end{array}$} & \multicolumn{2}{|c|}{ Number of d-21 isolates within clade } \\
\hline & & High & Low \\
\hline Bacillus licheniformis sensu lato & - & 13 & 6 \\
\hline Bacillus megaterium & $+/-$ & 0 & 1 \\
\hline Bacillus pumilus & - & 8 & 1 \\
\hline Bacillus safensis & - & 1 & 0 \\
\hline Bacillus subtilis sensu lato & - & 3 & 0 \\
\hline Bacillus weihenstephanensis & + & 19 & 1 \\
\hline Viridibacillus sp. & + & 1 & 0 \\
\hline Paenibacillus amylolyticus sensu lato & + & 3 & 0 \\
\hline Paenibacillus graminis & + & 6 & 2 \\
\hline Paenibacillus odorifer & + & 13 & 1 \\
\hline Paenibacillus cf. peoriae & + & 10 & 1 \\
\hline Paenibacillus sp. & + & 3 & 0 \\
\hline
\end{tabular}

${ }^{1}$ Cold-growth clade definitions and cold-growth clade status as described in Ivy et al. (2012).

${ }^{2}$ Sensu lato $=$ in the broad sense; $\mathrm{cf} .=$ unspecified identification, resembling the named species.

${ }^{3}+$ indicates $>5.0 \log \mathrm{cfu} / \mathrm{mL}$ growth over $21 \mathrm{~d}$ at $6^{\circ} \mathrm{C} ;+/$ - indicates limited growth $<3.5 \log \mathrm{cfu} / \mathrm{mL}$ over 21 d at $6^{\circ} \mathrm{C} ;-$ indicates no growth over $21 \mathrm{~d}$ at $6^{\circ} \mathrm{C}$. 
Table 4. Significance of independent variables in bivariate and multivariate logistic and linear regressions for the prediction of a farm being classified into the high category for sporeformer counts from spore-pasteurized bulk tank milk $\left[80^{\circ} \mathrm{C}\left(176^{\circ} \mathrm{F}\right)\right.$ for 12 min] and association with bulk tank SCC (BtSCC)

\begin{tabular}{|c|c|c|c|c|}
\hline Independent variable & \multicolumn{2}{|c|}{ Sporeformers ${ }^{1}$} & \multicolumn{2}{|r|}{$\mathrm{BtSCC}^{1}$} \\
\hline \multicolumn{5}{|l|}{ Milking time } \\
\hline Number of cows observed & - & - & - & - \\
\hline Number of milking unit falloffs & - & - & - & - \\
\hline Number of milking unit kickoffs & - & - & - & - \\
\hline How many people are milking each day? & - & - & - & - \\
\hline How many people are milking each week? & - & - & - & - \\
\hline How many people are milking each month? & - & - & - & - \\
\hline Is the California mastitis test used? ${ }^{4}$ & - & - & - & - \\
\hline Is the California mastitis test used at freshening? ${ }^{5}$ & - & - & + & $+(0$ vs. $2 ; 1$ vs. 2$)$ \\
\hline Is the California mastitis test used after the appearance of abnormal milk? ${ }^{5}$ & - & - & + & $(0,-10)$ \\
\hline How is the holding area cleaned? ${ }^{9}$ & - & - & - & - \\
\hline \multicolumn{5}{|l|}{ Parlor equipment } \\
\hline Is the hose a garden hose or larger diameter used for cleaning? ${ }^{10}$ & - & - & + & - \\
\hline Is treated water used in hoses to spray down equipment? ${ }^{5}$ & + & - & + & - \\
\hline What is the treated water treated with? ${ }^{11}$ & - & - & - & - \\
\hline Is the parlor deck washed down? ${ }^{5}$ & - & - & + & - \\
\hline How often is the parlor deck washed down? ${ }^{3}$ & - & - & - & - \\
\hline Is a hose or plumbed-in water used to wash the parlor deck? ${ }^{12}$ & - & - & + & - \\
\hline Is treated water used on the parlor deck? ${ }^{5}$ & - & - & - & - \\
\hline Are inflations changed on a schedule? ${ }^{4}$ & - & - & - & - \\
\hline How often are inflations changed? ${ }^{13}$ & - & - & - & - \\
\hline Are non-inflation rubber goods changed on a schedule? ${ }^{4}$ & - & - & + & - \\
\hline How often are rubber goods changed? ${ }^{14}$ & - & - & + & - \\
\hline How often is equipment serviced? ${ }^{14}$ & - & - & - & - \\
\hline How many times daily is the water tank area cleaned? ${ }^{19}$ & - & - & + & - \\
\hline Lactation area bedding type ${ }^{20}$ & - & - & + & - \\
\hline How often is bedding added to lactation area? ${ }^{21}$ & - & - & - & - \\
\hline Dry cow area bedding ${ }^{20}$ & - & - & + & - \\
\hline How often is bedding added to dry cow area? ${ }^{21}$ & - & - & - & - \\
\hline Maternity area bedding type $\mathrm{e}^{20}$ & - & - & + & - \\
\hline
\end{tabular}

of cows with dirty udders $(2.28$ mean $\mathrm{MPN} / \mathrm{mL}$ for farms with $>25 \%$ of cows with dirty udders and 0.78 and 0.61 mean $\mathrm{MPN} / \mathrm{mL}$ for farms with 0 to $10 \%$ and 11 to $25 \%$, respectively). Of farms that had 0 to $10 \%$ of cows with dirty udders, $54 \%$ were categorized as high and $46 \%$ were categorized as low. For farms with 11 to $25 \%$ of cows with dirty udders, $65 \%$ of farms were categorized as high and $35 \%$ were categorized as low. For farms that had $>25 \%$ of cows with dirty udders, $77 \%$ of farms were categorized as high and $23 \%$ were categorized as low (Figure 2). Percentage dirty udders appeared to have a greater influence on MPN levels than herd size. The MPN levels in bulk tank milk between farms classified into the 2 herd sizes differed by $0.55 \mathrm{MPN} / \mathrm{mL}$, whereas the MPN level for farms with $>25 \%$ of cows with dirty udders was 1.50 
Table 4 (Continued). Significance of independent variables in bivariate and multivariate logistic and linear regressions for the prediction of a farm being classified into the high category for sporeformer counts from spore-pasteurized bulk tank milk $\left[80^{\circ} \mathrm{C}\left(176^{\circ} \mathrm{F}\right)\right.$ for 12 min $]$ and association with bulk tank SCC (BtSCC)

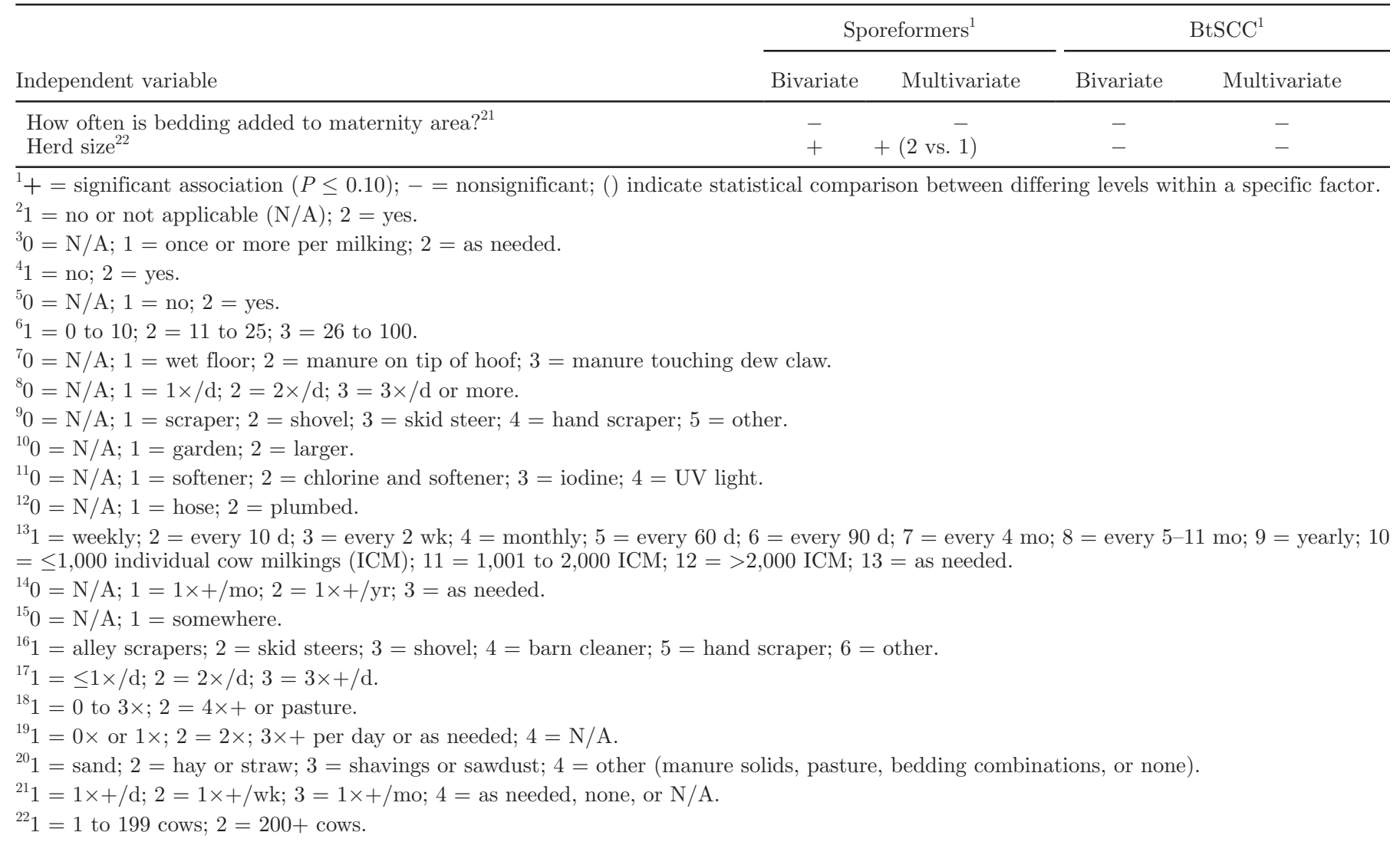

$\mathrm{MPN} / \mathrm{mL}$ higher than for farms with 0 to $10 \%$ of cows with dirty udders, and 1.67 MPN/mL higher than for farms with 11 to $25 \%$ of cows with dirty udders. It is important to note that our study data were limited by the questions included on our surveys (Table 4) and, thus, we may have not captured information about other important management factors that may potentially influence psychrotolerant sporeformer levels in bulk tank milk.

\section{Farm Management Practices Associated with High SCC in Bulk Tank Milk Overlap with Management Practices Associated with Farms Producing Milk Classified in the High Category After SP Treatment}

Bivariate analyses (with logarithm of BtSCC count for each farm as the outcome) were performed for all 47 farm management factors, resulting in the following 17 factors significantly associated with BtSCC: "Is

Table 5. Maximum likelihood estimates of logistic regression coefficients ( $\beta$ ), SE, adjusted odds ratios, and $95 \%$ CI for management factors associated with classification into the high farm category $\{\geq 3 \log \mathrm{cfu} / \mathrm{mL}$ for spore-pasteurized $\left[80^{\circ} \mathrm{C}\left(176^{\circ} \mathrm{F}\right)\right.$ for $\left.12 \mathrm{~min}\right]$ milk at any day of a 21 -d refrigerated storage period at $\left.6^{\circ} \mathrm{C}\right\}$

\begin{tabular}{|c|c|c|c|c|}
\hline Factor & $\begin{array}{c}\text { Factor } \\
\text { level }\end{array}$ & $\beta$ & $\mathrm{SE}$ & $\begin{array}{l}\text { Odds ratio } \\
(95 \% \mathrm{CI})\end{array}$ \\
\hline Intercept & - & -0.80 & 0.50 & \\
\hline \multirow[t]{3}{*}{ Percentage dirty udders in milking area } & 0 to 10 & - & - & - \\
\hline & 11 to 25 & 0.54 & 0.61 & $1.71(0.51-5.68)$ \\
\hline & $>25$ & 1.15 & 0.57 & $3.15(1.02-9.727)$ \\
\hline \multirow[t]{2}{*}{ Herd size } & 1 to 199 & 1.28 & 0.51 & $3.61(1.32-9.87)$ \\
\hline & $200+$ & - & - & - \\
\hline
\end{tabular}




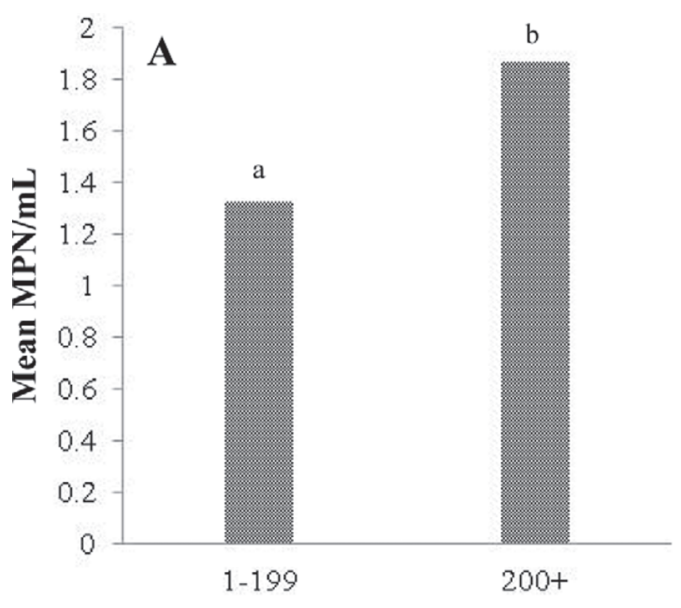

Herd size (no. of cows)

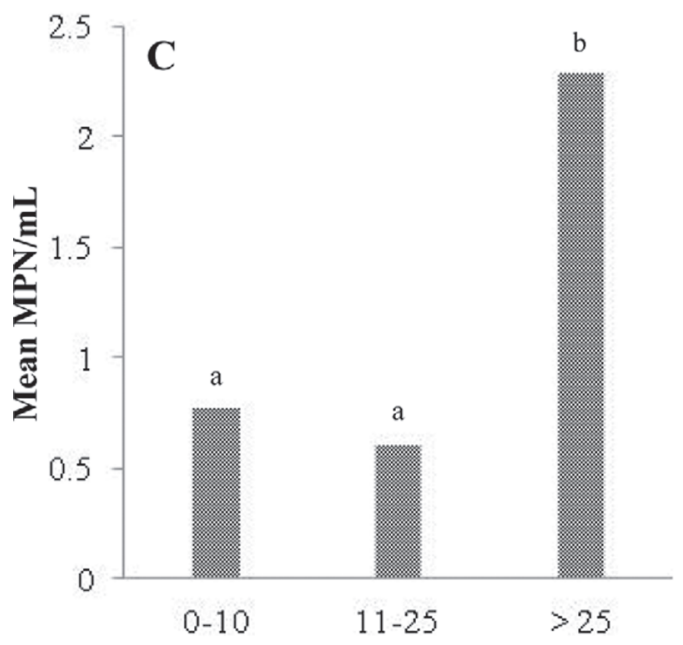

Dirty udders in milking area $(\%)$
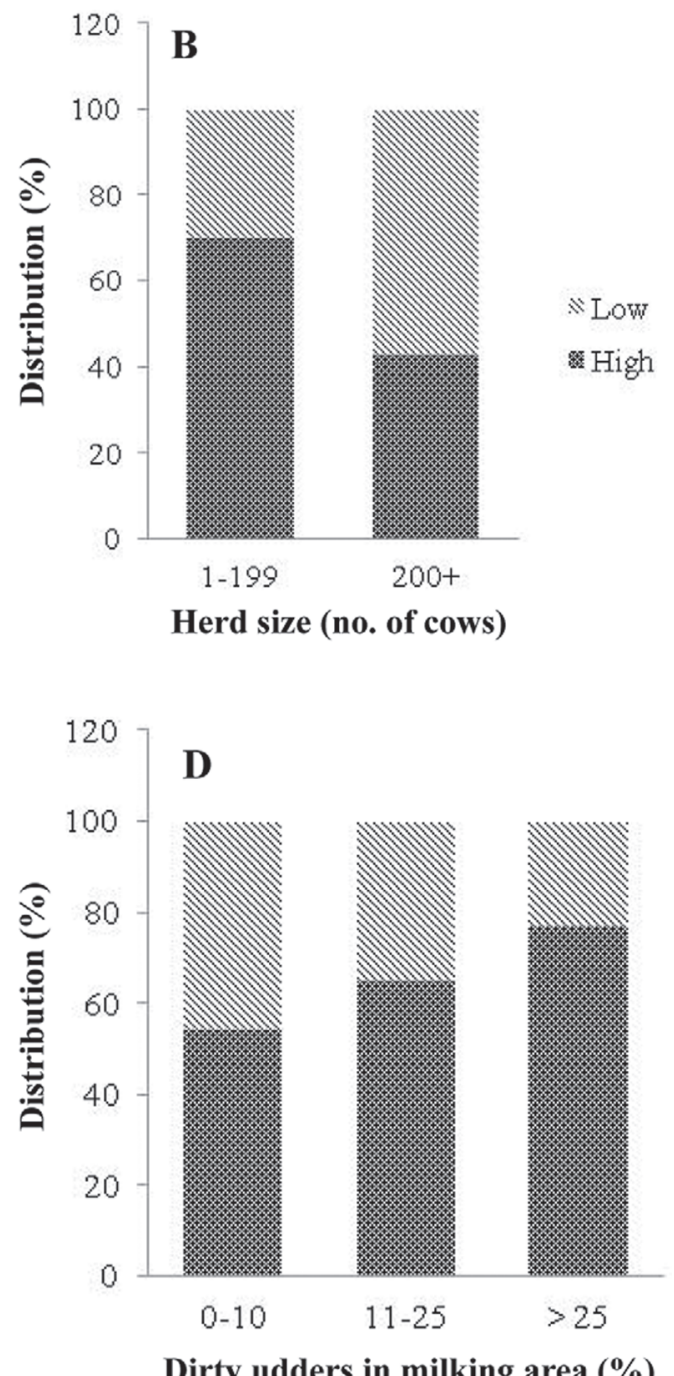

Figure 2. Relationships between management factors significantly associated with sporeformer counts after $21 \mathrm{~d}$ of refrigerated storage and sporeformer levels in bulk tank milk. (A) One-way ANOVA of most probable number (MPN) for farms with 1 to 199 cows or 200+ cows. (B) Distribution of high- and low-category farms for different herd sizes. (C) One-way ANOVA of MPN for farms with 0 to $10 \%, 11$ to $25 \%$, and $>25 \%$ cows with dirty udders in the milking parlor. (D) Distribution of high- and low-category farms for the different percentages of dirty udders ( 0 to $10 \%, 11$ to $25 \%$, and $>25 \%$ ). Different letters (a and b) between factor groups indicate a significant difference in the mean MPN per milliliter $(P<0.05)$.

the California mastitis test used at freshening?" "Is the California mastitis test used after the appearance of abnormal milk?" "percentage of cows with dirty udders in the milking area," "Is a garden hose or larger diameter hose used for cleaning?" (as an indicator of water flow used in the parlor), "Is treated water used in hoses to spray down equipment?" "Is the parlor deck washed down?" "Is a hose or plumbed-in water used to wash the parlor deck?" "Are non-inflation rubber goods changed on a schedule?" "How often are rubber goods changed?" "Is recycled water used on the farm?" "percentage of cows with dirty udders in the housing area," "Is the area around the water tank cleaned as often as the housing area?" "How many times daily is the water tank area cleaned?" "method of scraping housing area," "lactation area bedding type," "dry cow area bedding type," and "maternity area bedding type" (Table 4). "Percentage dirty udders in housing area" was removed from further analyses due to its correlation with "percentage dirty udders in the milking area," which was used for analysis instead. After multivariate analysis, 2 factors remained in the model: percentage dirty udders in the milking area $(P<0.10)$ and use of the California Mastitis Test at freshening $(P<0.10$; Table 4). Therefore, the final explanatory model indicated that more than $25 \%$ of cows observed with dirty 
udders coming into the milking parlor and lack of use of the California mastitis test at freshening significantly influenced BtSCC levels on farms.

\section{DISCUSSION}

Our study is the first to quantify associations between dairy farm management practices and post-heattreatment performance of refrigerated fluid milk. Multivariate analysis identified 2 factors (percentage dirty udders in the milking parlor and herd size) significantly associated with the likelihood of a farm having a high sporeformer level in their milk $(\geq 3 \log \mathrm{cfu} / \mathrm{mL}$ at any day after SP). These results suggest that adjustments to current cow hygiene practices may improve raw milk quality as well as pasteurized shelf-life performance.

\section{Standard Raw Milk Quality Parameters Showed Differences Between Raw Milk that Did and Did Not Show Bacterial Growth After SP}

Thirty-seven percent of the raw milk samples collected in this study showed limited or no bacterial growth following SP treatment and $21 \mathrm{~d}$ of refrigerated storage. These data suggest that a considerable proportion of commercially produced raw milk in NYS already could be processed into fluid milk products that show minimal microbial spoilage due to psychrotolerant sporeformer growth. This finding is important, as growth of psychrotolerant sporeformers is a major cause of fluid milk spoilage in the United States (Boor, 2001; Durak et al., 2006).

Raw milk with considerable bacterial growth after SP (classified as high category) showed significantly higher counts for some standard raw milk quality tests (i.e., PI count and PBC) compared with milk that was classified into the low category. However, numerical differences in results between these tests were relatively low $(<1 \log )$ and coefficient of determination values for correlations between standard raw milk quality tests and bacterial counts at d 21 after SP also were not very high $(<0.38)$, suggesting limited ability of current raw milk tests to predict post-SP milk performance as measured by psychrotolerant sporeformer counts. Not surprisingly, our data indicate that standard raw milk tests (BtSCC, raw milk SPC, PBC, and PI count) can identify raw milk that is characterized by overall lower quality and that poor-quality raw milk may perform less well than high-quality milk after SP treatment. These conclusions are consistent with results from previous studies, which reported a lack of strong predictive power for raw milk microbiological tests currently used in the dairy industry (e.g., PI count, PBC, and sporeforming bacteria counts) for pasteurized product shelf life (Boor et al., 1998; Martin et al., 2011). Those previous studies examined raw milk microbiological quality data and corresponding microbiological performance data over shelf life from commercial HTST pasteurized fluid milk products collected over 1-yr periods from 4 NYS milk processors.

In addition to standard raw milk quality tests, we also evaluated bulk tank milk quality using an MPN method for psychrotolerant sporeformers. Psychrotolerant sporeformer MPN differed significantly between milk samples categorized into the low and high categories; MPN values between these 2 categories differed by more than 10-fold, which was the largest test result difference observed between high- and low-category milk samples. Further, the proportion of SP-treated milk samples with MPN $<0.01$ was significantly larger among the samples in the low category compared with the high category. Although time consuming, requiring $21 \mathrm{~d}$ of incubation at $6^{\circ} \mathrm{C}$, the MPN test allows quantification of psychrotolerant sporeformers, which are a diverse group of organisms, including many Paenibacillus spp., some Bacillus spp. (e.g., B. weihenstephanensis), and Viridibacillus spp. With the goal of reducing detection and quantification time for critical milk spoilage organisms, a real-time quantitative PCR assay for specific detection of Paenibacillus spp. has been developed (Ranieri et al., 2012). Unfortunately, this assay does not detect psychrotolerant Bacillus and Viridibacillus spp. Our results suggest that a rapid test that detects a diverse array of psychrotolerant sporeformers in raw milk could allow for improved prediction of the performance of HTST pasteurized milk processed from this raw milk.

\section{Bacillus and Paenibacillus spp. Were the Predominant Sporeformers Isolated After SP}

Bacillus spp. and Paenibacillus spp. were the predominant spoilage organisms isolated from the sporepasteurized milk in the study reported here. Bacillus spp. were more commonly isolated than Paenibacillus spp. throughout this study. This result is in agreement with previous work that showed that the majority $(87 \%)$ of sporeformers isolated from dairy farm environment samples (bedding, feed, manure, soil, water, and bulk tank milk) were Bacillus spp. (Huck et al., 2008). The proportion of isolates classified as Paenibacillus was significantly higher in milk at d 14 and 21 after SP compared with milk at DI and d 7. These results are consistent with previous studies of pasteurized fluid milk spoilage patterns, which also reported increasing isolation rates of Paenibacillus spp. at over $21 \mathrm{~d}$ of refrigerated storage (Fromm and Boor, 2004; Ranieri et al., 2009; Ranieri and Boor, 2010). Previous 
work has shown that most Paenibacillus spp. isolated from pasteurized milk have the ability to grow at low temperatures, whereas only a few Bacillus spp. typically grow at low temperatures (Ivy et al., 2012).

Bacillus and Paenibacillus spp., including many of the same species found here, have been isolated from commercially pasteurized milk and milk products in the United States (Fromm and Boor, 2004; Huck et al., 2007a,b, 2008; Ranieri and Boor, 2009; Ivy et al., 2012), Europe (Schmidt et al., 2012; Lücking et al., 2013), and Africa (Aouadhi et al., 2014). Bacillus and Paenibacillus spp. also have been identified as the most common aerobic sporeformers in environmental samples from dairy processing facilities and dairy farms (Huck et al., 2007b, 2008; Ivy et al., 2012; Schmidt et al., 2012). Overall, these findings indicate that the psychrotolerant sporeformer populations found on farms represent spoilage organisms that are relevant in commercial products.

The proportion of isolates classified as Bacillus spp. and Paenibacillus spp. did not differ between high- and low-category farms. Whereas Paenibacillus spp. have been reported as more commonly having cold-growth abilities than Bacillus spp., our data support that coldgrowing Bacillus spp. are present in raw milk and present considerable potential for fluid milk spoilage (e.g., B. weihenstephanensis). Categorization of sporeformer subtypes isolated in the current study into clades associated with cold-growth phenotypes (Ivy et al., 2012) showed a numerically larger proportion of isolates from the high-category farms classified into clades associated with the cold-growth phenotype compared with isolates from the low category; however, some isolates from milk classified in the low category also were grouped with cold-growth clades (i.e., B. weihenstephanensis; Paenibacillus graminis, P. odorifer, and P. cf. peoriae). These observations suggest that isolates within a given clade may be diverse with regard to their ability to grow at low temperatures and indicate that further work is needed to identify specific genetic determinants responsible for cold-growth capabilities.

\section{On-Farm Management Practices Influence the Likelihood of High Sporeforming Spoilage Bacteria Levels in Bulk Tank Milk}

Based on the multivariate analysis of sporeformer data, we identified 2 management factors that were significantly associated with the likelihood of a farm producing milk that shows considerable bacterial growth during refrigerated storage after SP treatment. Specifically, farms with a high percentage of cows with dirty udders in the milking parlor and farms with less than 200 cows were more likely to have raw milk that showed considerable bacterial growth after SP. Despite the observation that larger farms were not as likely to be in the high category as smaller farms, our data indicated that, in this study, larger farms had slightly higher $(<1 \mathrm{MPN} / \mathrm{mL})$ MPN levels than smaller farms. The sporeforming bacteria present in the larger farm bulk tank samples appear to have been less capable of growing to high numbers at $6^{\circ} \mathrm{C}$ than the microbes present in the smaller farm bulk tank samples. These findings suggest that the presence of specific microorganisms that are capable of growing to high levels under refrigeration conditions is a better predictor of d-21 post-SP sporeformer numbers than the absolute number of sporeformers initially present in the bulk tank.

Other groups have examined relationships between farm size and milk quality. For example Ingham et al. (2011) reported that larger dairy farms in Wisconsin had significantly lower raw milk SPC and SCC than smaller farms. Another study reported that dairy farmers with smaller herd sizes were more likely to have management styles described as "clean and accurate" than as "quick and dirty" (Barkema et al., 1999). However, their study also reported that the quality of management practices used to decrease BtSCC did not differ between the 2 management styles, suggesting a weak relationship between herd sizes and milk quality, although this point was not explicitly tested in the study. Increasing herd size alone is unlikely to be a practical management choice for reducing sporeformer numbers in bulk tank milk. As a management factor, herd size is likely a proxy for multiple farm variables, including economic resources (e.g., labor or bulk tank type and cooling ability) available for milk quality efforts.

The second management factor identified as a risk factor for farm classification into the high category was percentage dirty udders. This management factor not only lends itself to intervention, but was also found to have a significant effect on psychrotolerant sporeformer MPN in raw milk, with farms with a higher percentage of dirty udders having substantially higher MPN. The importance of udder cleanliness for psychrotolerant spore contamination of raw milk is logical, as sporeforming bacteria have been found throughout the dairy farm environment, including in bedding, feed, manure, soil, and water (Scheldeman et al., 2005; Huck et al., 2008) and, hence, can easily be transferred to the udder and into raw milk. Previous studies suggested that adopting more hygienic practices to ensure clean udders before milking may be feasible, economical, and relatively simple. For example, Vissers et al. (2007) reported a 100-fold difference (3 to $300 \mathrm{mg} / \mathrm{L}$ ) in the quantity of dirt present on udders between farms with 
good-hygiene practices and farms with poor-hygiene practices. Another study found that poor teat-end cleanliness was associated with higher bacteria counts in bulk tank milk (Elmoslemany et al., 2009). Further, adopting the hygienic practice of cleaning teats with moist paper towels reduced the number of Clostridia tyrobutyricum spores isolated from raw milk (Magnusson et al., 2006).

To determine whether the same or different practices affect both a traditional milk-quality parameter (i.e., BtSCC) as well as parameters related to the presence of psychrotolerant sporeformers, we also performed a multivariate analysis for associations of management factors with BtSCC. This analysis showed that a lower percentage of dirty udders in the milking parlor and use of a California mastitis test at freshening both were significantly associated with lower BtSCC. Barkema et al. (1999) also reported that farms with low BtSCC had better observed animal-hygiene scores. Associations between use of a California mastitis test specifically at freshening and lower BtSCC can be explained by the fact that freshening is a crucial time to mitigate IMI and subsequent SCC levels (Oliver et al., 2003). Another study reported that SCC was lower for cows that were assigned to a California mastitis test-based treatment program for subclinical mastitis compared with cows that were assigned to the control program (no California mastitis test usage; Lago et al., 2012).

Overall, our data indicate that milking time practices used to control mastitis on dairy farms (specifically those practices affecting udder cleanliness) may also help control psychrotolerant sporeformer levels in bulk tank milk. Therefore, focusing on cow cleanliness may yield the dual benefits of achieving raw-milk-quality economic incentives for producers and improved pasteurized product performance for consumers.

\section{CONCLUSIONS}

As the dairy industry ships milk farther and longer between farm of origin and location of consumption (Womble et al., 2008), controlling the presence of sporeforming spoilage organisms throughout the milk production and processing continuum is essential for producing high-quality, long-lasting fluid milk products. Our study identified dairy farm management practices related to milking time hygiene that may simultaneously lower BtSCC on dairy farms as well as psychrotolerant sporeformer levels in bulk tank milk. On-farm adjustments in management decisions specifically focused on udder cleanliness may directly affect the shelf life of pasteurized fluid milk. Our data reported here represent the microbiological quality of bulk tank milk obtained at a single time point on each farm. Additional studies are needed to determine if farms can consistently produce raw milk that does not show bacterial growth following heat treatment.

\section{ACKNOWLEDGMENTS}

This project was supported by the New York State Milk Promotion Advisory Board contract \#C200708 through the New York State Department of Agriculture and Markets (Brooklyn, NY) and by the Cornell University Agricultural Experiment Station federal formula funds (Project No. NYC-478426) received from the National Institute of Food and Agriculture (NIFA, Washington, DC) United States Department of Agriculture. The authors thank the management and employees of all participating farms, Cornell University Quality Milk Production Services (Ithaca, NY) technicians for sample and survey collection, Matthew Ranieri and Laura Strawn (both from Cornell University) for critical review of the manuscript, as well as members of Cornell University Milk Quality Improvement Program for laboratory support.

\section{REFERENCES}

Ageitos, J. M., J. A. Vallejo, A. B. F. Sestelo, M. Poza, and T. G. Villa. 2007. Purification and characterization of a milk-clotting protease from Bacillus licheniformis strain USC13. J. Appl. Microbiol. 103:2205-2213.

Aouadhi, C., A. Maaroufi, and S. Mejri. 2014. Incidence and characterisation of aerobic spore-forming bacteria originating from dairy milk in Tunisia. Int. J. Dairy Technol. 67:95-102. http://dx.doi. org/10.1111:1471-0307.12088.

Barkema, H. W., J. D. Van der Ploeg, Y. H. Schukken, T. J. G. M. Lam, G. Benedictus, and A. Brand. 1999. Management style and its association with bulk milk somatic cell count and incidence rate of clinical mastitis. J. Dairy Sci. 82:1655-1663.

Boor, K. J. 2001. ADSA Foundation Scholar Award: Fluid dairy product quality and safety: Looking to the future. J. Dairy Sci. $84: 1-11$.

Boor, K. J., D. P. Brown, S. C. Murphy, S. M. Kozlowski, and D. K. Bandler. 1998. Microbiological and chemical quality of raw milk in New York State. J. Dairy Sci. 81:1743-1748.

Boor, K. J., and S. C. Murphy. 2002. Microbiology of market milks. Pages 91-122 in Dairy Microbiology Handbook: The Microbiology of Milk and Milk Products. 3rd ed. R. K. Robinson, ed. John Wiley \& Sons Inc., Hoboken, NJ.

Buzby, J. C., and J. Hyman. 2012. Total and per capita value of food loss in the United States. Food Policy 37:561-570.

Collins, E. B. 1981. Heat resistant psychrotrophic organisms. J. Dairy Sci. 64:157-160.

Crielly, E. M., N. A. Logan, and A. Anderton. 1994. Studies on the Bacillus flora of milk and milk products. J. Appl. Bacteriol. $77: 256-263$.

Dairy Team Extension. 2002. Hygiene scoring card. University of Wisconsin, Madison. Accessed Feb. 13, 2014. http://www.vetmed. wisc.edu/dms/fapm/fapmtools/4hygiene/hygiene.pdf.

Davidson, P. M., L. A. Roth, and S. A. Gambrel-Lenarz. 2004. Coliform and other indicator bacteria. Pages 196-197 in Standard Methods for the Examination of Dairy Products. 17th ed. H. M. Wehr and J. F. Frank, ed. Am. Public Health Assoc., Washington, DC. 
Dugan, K. A., H. S. Lawrence, D. R. Hares, C. L. Fisher, and B. Budowle. 2002. An improved method for post-PCR purification for mtDNA sequence analysis. J. Forensic Sci. 47:811-818.

Durak, M. Z., H. I. Fromm, J. R. Huck, R. N. Zadoks, and K. J. Boor. 2006. Development of molecular typing methods for Bacillus spp. and Paenibacillus spp. isolated from fluid milk products. J. Food Sci. 71:M50-M56.

Dutt, K., P. Gupta, S. Saran, S. Misra, and R. K. Saxena. 2009 Production of milk-clotting protease from Bacillus subtilis. Appl. Biochem. Biotechnol. 158:761-772.

Elmoslemany, A. M., G. P. Keefe, I. R. Dohoo, and B. M. Jayarao. 2009. Risk factors for bacteriological quality of bulk tank milk in Prince Edward Island dairy herds. Part 1: Overall risk factors. J. Dairy Sci. 92:2634-2643.

FDA (Food and Drug Administration). 2011. Standards for grade "A" milk and milk products. Pages 27-30 in Grade "A" Pasteurized Milk Ordinance. Standards for grade "A" milk and milk products. US Department of Health and Human Services, Public Health Service, Washington, DC.

Fredrickson, J. K., and T. C. Onstott. 1996. Microbes deep inside the earth. Sci. Am. 275:68-73.

Fromm, H. I., and K. J. Boor. 2004. Characterization of pasteurized fluid milk shelf-life attributes. J. Food Sci. 69:M207-M214.

Gilliam, M. 1985. Microbes from apiarian sources: Bacillus spp. in frass of the greater wax moth. J. Invertebr. Pathol. 45:218-224.

Gilliam, M., S. L. Buchmann, and B. J. Lorenz. 1984. Microbial flora of the larval provisions of the solitary bees, Centris pallida and Anthophora sp. Apidologie (Celle) 15:1-10.

Gunders, D. 2012. Wasted: How America is losing up to 40 percent of its food from farm to fork to landfill. Natural Resources Defense Council. Accessed Jan. 6, 2013. http://www.nrdc.org/food/files/ wasted-food-ip.pdf.

Huck, J. R., B. H. Hammond, S. C. Murphy, N. H. Woodcock, and K. J. Boor. 2007a. Tracking spore-forming bacterial contaminants in fluid milk-processing systems. J. Dairy Sci. 90:4872-4883.

Huck, J. R., M. Sonnen, and K. J. Boor. 2008. Tracking heat-resistant, cold-thriving fluid milk spoilage bacteria from farm to packaged product. J. Dairy Sci. 91:1218-1228.

Huck, J. R., N. H. Woodcock, R. D. Ralyea, and K. J. Boor. 2007b. Molecular subtyping and characterization of psychrotolerant endospore-forming bacteria in two New York State fluid milk processing systems. J. Food Prot. 70:2354-2364.

IDFA (International Dairy Foods Association). 2010. Fluid milk sales and consumption. Pages 66-76 in Dairy Facts: 2010 Edition. IDFA, Washington, DC.

Ingham, S. C., Y. Hu, and C. Ané. 2011. Comparison of bulk-tank standard plate count and somatic cell count for Wisconsin dairy farms in three size categories. J. Dairy Sci. 94:4237-4241.

Ivy, R. A., M. L. Ranieri, N. H. Martin, H. C. den Bakker, B. M. Xavier, M. Wiedmann, and K. J. Boor. 2012. Identification and characterization of psychrotolerant sporeformers associated with fluid milk production and processing. Appl. Environ. Microbiol. 78:1853-1864.

Lago, A., S. Godden, R. Bey, K. Leslie, and P. Ruegg. 2012. Efficacy of two fresh cow subclinical mastitis treatment programs. Pages 293-293 in Udder Health and Communication. H. Hogeveen and T. J. G. M. Lam, ed. Wageningen Academic Publishers, Wageningen, the Netherlands.

Laird, D. T., A. Gambrel-Lenarz, F. M. Scher, T. E. Graham, and R. Reddy. 2004. Microbiological count methods. Pages 153-186 in Standard Methods for the Examination of Dairy Products. 17th ed. H. M. Wehr and J. F. Frank, ed. Am. Public Health Assoc., Washington, DC.

Lücking, G., M. Stoeckel, Z. Atamer, J. Hinrichs, and M. EhlingSchulz. 2013. Characterization of aerobic spore-forming bacteria associated with industrial dairy processing environments and product spoilage. Int. J. Food Microbiol. 166:270-279.
Magnusson, M., A. Christiansson, B. Svensson, and C. Kolstrup. 2006. Effect of different premilking manual teat-cleaning methods on bacterial spores in milk. J. Dairy Sci. 89:3866-3875.

Martin, N. H., M. L. Ranieri, S. C. Murphy, R. D. Ralyea, M. Wiedmann, and K. J. Boor. 2011. Results from raw milk microbiological tests do not predict the shelf-life performance of commercially pasteurized fluid milk. J. Dairy Sci. 94:1211-1222.

Nicholson, W. L. 2002. Roles of Bacillus endospores in the environment. Cell. Mol. Life Sci. 59:410-416.

Oliver, S. P., M. J. Lewis, B. E. Gillespie, H. H. Dowlen, E. C. Jaenicke, and R. K. Roberts. 2003. Prepartum antibiotic treatment of heifers: Milk production, milk quality and economic benefit. J. Dairy Sci. 86:1187-1193.

Ranieri, M. L., and K. J. Boor. 2009. Short communication: Bacterial ecology of high-temperature, short-time pasteurized milk processed in the United States. J. Dairy Sci. 92:4833-4840.

Ranieri, M. L., and K. J. Boor. 2010. Tracking and eliminating sporeformers in dairy systems. Aust. J. Dairy Technol. 65:74-80.

Ranieri, M. L., J. R. Huck, M. Sonnen, D. M. Barbano, and K. J. Boor. 2009. High temperature, short time pasteurization temperatures inversely affect bacterial numbers during refrigerated storage of pasteurized fluid milk. J. Dairy Sci. 92:4823-4832.

Ranieri, M. L., R. A. Ivy, W. R. Mitchell, E. Call, S. N. Masiello, M. Wiedmann, and K. J. Boor. 2012. Real-time PCR detection of Paenibacillus spp. in raw milk to predict shelf life performance of pasteurized fluid milk products. Appl. Environ. Microbiol. 78:5855-5863.

Sarkar, A. 1991. Isolation and characterization of thermophilic, alkaliphilic, cellulose-degrading Bacillus thermoalcaliphilus sp. nov. from termite (Odontotermes obesus) mound soil of a semiarid area. Geomicrobiol. J. 9:225-232.

Scheldeman, P., L. Herman, J. Goris, P. De Vos, and M. Heyndrickx. 2002. Polymerase chain reaction identification of Bacillus sporothermodurans from dairy sources. J. Appl. Microbiol. 92:983-991.

Scheldeman, P., A. Pil, L. Herman, P. De Vos, and M. Heyndrickx. 2005. Incidence and diversity of potentially highly heat-resistant spores isolated at dairy farms. Appl. Environ. Microbiol. 71:1480-1494.

Scheldeman, P., M. Rodríguez-Díaz, J. Goris, A. Pil, E. De Clerck, L. Herman, P. De Vos, N. A. Logan, and M. Heyndrickx. 2004. Bacillus farraginis sp. nov., Bacillus fortis sp. nov. and Bacillus fordii sp. nov., isolated at dairy farms. Int. J. Syst. Evol. Microbiol. 54:1355-1364.

Schmidt, V. S. J., V. Kaufmann, U. Kulozik, S. Scherer, and M. Wenning. 2012. Microbial biodiversity, quality and shelf life of microfiltered and pasteurized extended shelf life (ESL) milk from Germany, Austria and Switzerland. Int. J. Food Microbiol. 154:1-9.

te Giffel, M. C., A. Wagendorp, A. Herrewegh, and F. Driehuis. 2002. Bacterial spores in silage and raw milk. Antonie van Leeuwenhoek $81: 625-630$.

Vaerewijck, M. J. M., P. De Vos, L. Lebbe, P. Scheldeman, B. Hoste, and M. Heyndrickx. 2001. Occurrence of Bacillus sporothermodurans and other aerobic spore-forming species in feed concentrate for dairy cattle. J. Appl. Microbiol. 91:1074-1084.

Vissers, M. M. M., F. Driehuis, M. C. Te Giffel, P. De Jong, and J. M. G. Lankveld. 2007. Short communication: Quantification of the transmission of microorganisms to milk via dirt attached to the exterior of teats. J. Dairy Sci. 90:3579-3582.

Washam, C. J., H. C. Olson, and E. R. Vedamuthu. 1977. Heat-resistant psychrotrophic bacteria isolated from pasteurized milk. J Food Prot. 40:101-108.

Womble, P., L. Hopper, C. Thompson, S. M. Alexander, W. Crist, F. Payne, T. Stombaugh, J. Paschal, R. Moore, and B. Luck. 2008. A wireless electronic monitoring system for securing milk from farm to processor. Page 694315-694316 in SPIE defense and security symposium. International Society for Optics and Photonics, Bellingham, WA. 